This is a self-archived - parallel published version of this article in the publication archive of the University of Vaasa. It might differ from the original.

\title{
Credit Unions and Co-operative Banks Across the World
}

Author(s): Goglio, Silvio; Kalmi, Panu

Title: $\quad$ Credit Unions and Co-operative Banks Across the World

Year: $\quad 2017$

Version: Accepted manuscript

Copyright (C) 2017 Oxford University Press

Please cite the original version:

Goglio, S., \& Kalmi, P., (2017). Credit Unions and Co-operative Banks Across the World. In: Michie, J., Blasi, J.R. \& Borzaga, C. (eds). The Oxford Handbook of Mutual, Co-operative, and Coowned Business. Oxford University Press. https://doi.org/10.1093/oxfordhb/9780199684977.013.10 


\section{Credit Unions and Co-operative Banks Across the World}

Silvio Goglio and Panu Kalmi ${ }^{1}$

\section{The Main Features of Financial Co-operatives}

Today credit co-operatives represent a wide range of institutions, which reflect the needs of members and the specificities of national legislative frameworks. Their ability to adapt and grow in highly diverse economic and institutional environments has allowed them to become a substantial part of the banking industry. The sector embraces systems that are not entirely uniform in terms of legal and regulatory provisions, size, and organisation: some are strongly integrated, others are more diversified. Each pattern has its strengths and weaknesses. Close coordination at central level can help overcome constraints and inefficiencies due to the small size of individual co-operative banks. On the other hand, entrepreneurial autonomy fosters competition, the quest for innovative solutions, and the ability to adapt to the needs of local economies. However, there are some crucial features that from the very beginning characterized credit co-operatives and still distinguish, even if with growing difficulty, the descending business model.

The most important of these features are democratic governance and mutualism. The democratic governance of credit co-operatives is based on three principles: the 'open door' principle, according to which everyone is eligible to become a member; the company

\footnotetext{
${ }^{1}$ We thank Yiorgos Alexopoulos, Holger Blisse and Eric Meyer for their kind help in answering our queries when writing this article.
} 
capital consisting of shares of nominal value; the 'one member-one vote' principle whereby, regardless of the number of shares, each member has only one vote in meetings. Ownership rights only stem from membership and are unrelated with the amount of shares, making takeovers highly improbable. Their mutuality rests on the commitment to devote their main activities to members, and to be not for profit, since they do not maximize profits, but the wellbeing of members. Other crucial features, stemming from the first two, are: solidarity, local identity, and a stronger pledge to ethical behaviour.

These underlying principles determine the specialization and the business model of financial co-operatives, which rely heavily on relationship-based retail banking and the commitment to invest in the real economy and to create benefits for members, customers, and communities. The core values of this model are, among others, prudence, responsiveness, empathy, and transparency. Many potential effects may stem from this attitude: first, a tendency to adopt less risky strategies and to have much lower volatility of returns, with positive consequences for the financial stability of the territories where they

operate; second, the propensity to defend consumer interests and maximize consumer surplus, offering simple and transparent products, fairly priced and well-designed to meet local needs; third, a lower inclination, during a credit crunch, to ration credit to customers and to raise loan interest rates, thanks to better capitalization and more prudent lending.

\section{Raiffeisen Model vs. Schultze-Delitzch Model}

The origin of co-operative credit dates back to the mid-nineteenth century in Germany, immediately after the first co-operative of modern form, the Rochdale Pioneers' Equitable Society, was founded in December 1844. From the outset, the German movement attributed a central role to credit by proposing a new model of development for marginalized areas 
and small operators, who at the time were forced to resort to private lenders, often usurers. The first initiatives were undertaken in urban areas by Hermann Schulze Delitzsch. The essential requirements of his Volksbanken, or People's Banks, were the concept of Selbsthilfe (self-help), the general assembly as the main body of governance and the election of the executive and control bodies following the 'one man, one vote' principle. Capital had to be constituted through participating shares acquired by individual members. The obligatory acquisition of one or more capital shares served both to restrict access only to people able to help themselves, and to stimulate members to form their own capital. Finally, the people's banks had to pay their members dividends deriving from operating profits, so as to attract people wanting to invest their savings and to encourage capital contributions.

The Volksbanken became definitively established from 1852 onwards and expanded also beyond German borders. Nevertheless, they were unable to take root in rural areas and to answer the needs of a peasant society. It was consequently necessary to re-interpret Schulze's model so that it matched rural realities. This challenge was taken up by Friedrich Wilhelm Raiffeisen who adopted some of Schulze principles, as the Selbsthilfe, and, like all co-operative institutions, the democratic administration of the bank. Unlike the people's banks, his Darlehenskassenvereine must restrict the geographical area in which they operated as much as possible, in order to allow members to have detailed knowledge of the economic and moral situations of co-members.

The models developed by Raiffeisen and Schulze-Delitzsch both envisaged credit co-operative as the pivot of a complex system of associations operating in the area of consumption and production. However, although Raiffeisen started from theoretical 
considerations similar to those of Schulze, there was no homogeneity between their models. The basic difference sprang from the different ideal aspirations and from the overall purpose they attributed to co-operatives. For Raiffeisen the co-operative creed drove a Universalist endeavour to render social co-living more harmonious: the tendency not to seek profit for its own sake but for the benefit of all members alike was a matter of principle based on Christian solidarity. Instead, co-operatives based on Schulze's model applied similar founding principles with a view to immediate economic utility, and were considered an essentially economic movement regardless of religious beliefs. The force of Schulze-Delitzsch's message lay in its pragmatic capacity to meet the needs of the lower middle class. This dispute was joined by Wilhelm Haas, who founded in 1883 the Union of Agricultural Co-operatives, with the approval of Schulze-Delitzsch, by then convinced that it was impossible to unite urban and agricultural co-operatives within a single federation. The underlying principle was, as Raiffeisen had argued, that rural society required an autonomous and independent co-operative union. Nevertheless, any religious vocation was regarded as superfluous; following the conviction that pure co-operation was possible by adapting Schulze's commercial ideas to the countryside.

\section{Adaptations of the Model: the Credit Union Model in the US and Canada}

The credit union model was initially created at the beginning of the 20th century in North America as an extension of the Raiffeisen model. The first credit unions were established in the Francophone regions of Canada, mostly Quebec. From these credit unions the powerful Desjardins Group later developed. In the Anglophone regions of Canada credit unions developed more slowly, in Atlantic provinces starting in the 1930s and in the Western provinces mostly after WWII. Even today important differences between the Francophone 
and Anglophone credit unions remain, the former being organized in a tighter network and the latter often being larger and more independent.

The US credit union system developed rather independently. Its main sponsor was the wealthy Boston retail store magnate Edward Filene. Their formation speeded up considerably after Filene hired the attorney Roy Bergengren to lead the Massachusetts Association of Credit Unions in 1920 and a year later Credit Union Extension Bureau was established. The Bureau promoted legislation initially at the state level. In the year 1934 a law enabling the formation of federal credit unions was passed. In the same year the Credit Union National Association (CUNA) was formed. Credit unions turned out to be fairly resistant in the Great Depression and this helped consolidate their position in the US.

Between the 1930s and the 1990s, the US banking system was characterized by a greatly decentralized structure and thousands of small and regional commercial banks coexisted with savings and loans associations. Credit unions were clearly the smallest in aggregate and by average size. However, their significance started increasing in the 1980s due to the Savings and Loans Crisis, when a large proportion of the savings and loans sector was either demutualized or went bankrupt. Credit unions, in turn, weathered the 1980s recession and financial market deregulation rather well. A further development that increased their prominence was the liberalization of the common bond restrictions in 1998 . Thereafter, credit union membership grew rapidly. As of 2015, credit unions in the US have over 100 million members.

There are important differences between credit unions and European co-operative banks. First, membership has been, at least historically, rather different. While European credit co-operatives were territorially based and often included farmers as members, the 
membership of credit unions in the US was typically defined by employer. Recent changes, including the decrease of the farmer population and the broadening of the membership in Europe and the liberalization of the common bond system in the US, have brought the membership policies closer to each other. Another important difference is that credit unions only do business with their members, whereas European credit co-operatives typically also allow non-member customers. Moreover, credit unions are more focused on consumer lending, especially in the US. Their network structure is much looser and competition among credit unions is common. Even though federal and state associations exist, their role is much smaller than in Europe.

\section{Further Developments of the Model: Integration in Financial Co-operatives}

Many types of co-operatives have a network structure, where individual co-operatives form second level co-operatives that aim to support the functioning of primary level cooperatives. They often have a variety of activities, including marketing, lobbying, educating members and their representatives, and organizing employee training. Probably in no other co-operative sector are networks as important as in the financial sector. In addition to the previously mentioned areas, in banking there are a number of other areas that require considerable economies of scale. Centrals of financial co-operatives have an important role as clearing partners in the payment system and as representatives of the banking group in matters towards the central bank, such as participating in the open market operations of central banks. Co-operative centrals also manage the liquidity within the system, allocating the savings from banks with deposit surplus to those with deposit deficit, investing the surplus in the interbank markets, and borrowing in the case of deficit. Centrals often have a credit rating that allows them to borrow from the market more cheaply than individual co- 
operative banks. Co-operative centrals are involved in many areas in which individual cooperatives would find it difficult to engage alone, such as organizing e-banking, credit cards, or mutual funds. Finally, co-operative centrals and their daughter companies are also engaged in large investment projects, for instance in corporate finance.

It is important to notice that co-operative centrals as such are nothing new. Already Raiffeisen had organized co-operative networks on a regional basis. These regional centrals for instance had an important role in auditing and training the personnel of local cooperatives. However, due to the increase of non-traditional activities in co-operatives, the role of the centrals has become even more important. Their role has also become more important due to the actions of regulators and rating agencies. Regulators often prefer to deal with one contact point rather than with a network of independent banks. Similarly, rating agencies tend to prefer systems where there is a strong central and joint liability of the debts of banks within the network, and they have even assigned higher ratings for networks that have this type of structure.

Several benefits derive from network structures, as well as governance challenges. Without far-reaching network structures the viable minimum size for co-operatives would likely to be much larger. Networks perform operations for which small co-operatives would not have required scale, and allow small co-operatives to focus on issues where small size yields better information and therefore competitive advantage, such as lending to local enterprises. Similarly, member participation in co-operative governance is likely to be more intensive when the size of the co-operative is smaller. For their part, networks are also effective in solving the governance challenges of co-operatives. First-tier co-operatives do not need to rely on monitoring by members only, but there is also supplementary (or 
perhaps primary) monitoring by the network. Especially when combined with the audit function, there are clear information benefits from getting the network to do the monitoring.

Sometimes networks of co-operative banks get involved in much riskier activities than banks at the local or regional level. Examples include varieties of corporate and infrastructure finance projects, investment banking activities, and internationalization of cooperative banks. While these services are often related to the needs of members in a dynamic environment, in some cases involvement in these services can be motivated by increases in managerial prestige and pay. Proper analysis of such risky undertakings often requires more elaborate governance systems and risk management methods than cooperative banks have available.

The degree of network integration varies considerably. Desrochers and Fischer (2005) differentiate between atomic, consensual, and strategic networks: the mature networks of financial co-operatives typically belong to the latter two. Examples of consensual networks include US credit unions, Italian Banche Popolari, and Spanish cooperatives. Most continental European co-operative groups, as well as the Desjardins Group in Quebec, form to the strategic networks. In fact, strategic network have even more elaborate structures, including those with joint liability (Dutch Rabobank and Finnish OP Group).

\section{Internal and External Competition in Financial Co-operatives}

Traditionally, retail banking has been the core of co-operative banks' business. Their strength in this sector has hinged on their robust establishment in the territory and vigorous participation in the life of the community, as well as on their ability to establish closer and more flexible relationships with small- and medium-sized firms and to monitor their 
profitability. These qualities often have off-set disadvantages of scale and generate system economies of various kinds, not necessarily economic ones. Recent times have seen an increase in competition in retail banking, mainly from commercial banks, trying to recover market shares and profits, often lost in the recent financial crisis, through relational finance. This policy is implemented not only by local banks, but also by big national and international banks both by reinforcing local branches and through the acquisition of local banks. A second source of increased competition for co-operative banks arises from fellow co-operative banks.

This picture is correlated with local identity - the traditional source of strength of credit co-operatives-losing importance in the financial decisions of small firms and families vis-à-vis reasons derived by economic calculation. In this context, co-operative banks' pyramidal organizational structure - the historic reaction to their small scale weaknesses - and their recent process of consolidating or defensive mergers, which aim to cut costs and possibly also diversify risks, can definitely create synergies. Nevertheless, they are altering some fundamental characteristics of the grass-root initiative and of the cooperative movement. As a consequence, the competition between the two models of banking - one based on social cohesion and solidarity and the other on self-interest-is losing importance toward a simpler and reductive competition on market excellence.

\section{The Performance of Financial Co-operatives: Various Measures and their Situation during the Crisis}

Measurement of performance in financial co-operatives is considerably trickier than in investor-owned banks. Well-diversified investors only care about the returns on their investment therefore the return on equity (ROE) provides a natural measure on the 
performance of investor-owned banks. However, the members of financial co-operatives, who are depositors and borrowers, in addition care at least of the following: loan rates, deposit rates, riskiness of the co-operative, and the quality of the services. In other words, it is difficult to gauge the performance of financial co-operatives using a single measure. The performance of co-operative banks vs. other types of banks has been studied in two ways: by analysing ratios (for instance, return on equity or assets, loan loss provisions to total loans, or cost-to-income ratios) and by means of formal efficiency analysis (for instance, stochastic frontier analysis). In both cases, a wide variety of approaches, samples, and even definitions of co-operatives has been used. In particular, we can distinguish among studies that compare the determinants of performance within co-operatives; studies that compare the performance of co-operatives and profit-maximizing banks; and studies that compare the performance of co-operative banks relative to profit-maximizing banks before and during the European financial and economic crisis that started in 2008 and is still evident in most parts of Europe at the time of writing (in 2015). Often these studies find quite contradictory results: for instance, there has been no consensus on whether co-operative banks were at profitability disadvantage before the crisis, even though it seems clear that at least during the crisis co-operative banks no longer had poorer profitability. Also, some studies found that co-operative banks are more efficient than shareholder banks, whereas other studies concluded the opposite.

Co-operative financial organizations typically start out small and, at least traditionally, were viewed to have some advantages of small size, including better information about borrowers and the possibility to impose social sanctions to nonperforming members. For a variety of reasons, including technological innovations, many observers have argued that lately the value of soft information in banking has decreased. 
For co-operative banks, a practical implication of this may be that the optimal size of cooperative banks has increased. This issue has been studied empirically most often in the US, where the research has often uncovered evidence that suggests that credit unions would benefit from increasing their size. European co-operative banks have been studied much less in this respect. The few studies that exist typically do not find significant economies of scale or benefits from mergers. This difference in results may arise from different network structures: European co-operative groups are typically much more tightly integrated than US credit unions and this may help them operate on a smaller optimal scale.

The financial crisis that broke out in 2007-2008 revitalized the interest towards cooperative banks largely because these were perceived to be more stable than profitmaximizing banks. Groeneveld and de Vries (2009) provided some early evidence that cooperative banks were less affected by the subprime crisis than large shareholder banks, and this view was further reinforced by Birchall (2013). Ferri, Kalmi, and Kerola (2014a,b; 2015) provided an evaluation of the performance of co-operatives banks vs. savings and shareholder banks using quantitative analysis of large samples up to the end of 2011. One of their findings is that profitability of co-operative banks declined only marginally during the crisis, while the profitability of shareholder banks declined considerably, so that the pre-crisis wedge in profitability between co-operative and shareholder banks disappeared. Co-operative banks had better loan quality than shareholder banks already before the crisis, and this difference only became more pronounced during the crisis. Also the bank stability ratings of tightly integrated co-operative banks deteriorated much less during the crisis than those of shareholder banks. Lending by co-operative banks varied much less than that of shareholder banks and co-operative banks also showed less responsiveness to monetary 
policy changes, both before and during the crisis. This suggests that co-operative banks have smooth lending cycles and can therefore be beneficial to overall economic stability.

However, it must be said that the record of co-operative banks during the crisis is not consistently positive, and many negative developments have occurred after 2011. Unsurprisingly, in countries where there has been severe economic disruption also cooperatives have encountered grave difficulties. This applies to Cypriot co-operatives, which have been nationalized, and to Greek co-operatives, whose number has been drastically reduced by mergers. Some co-operatives also experienced trouble despite the fact they were located in less adverse environments. One of the earliest co-operatives to experience crisis was the Austrian Volksbank Corporation, which suffered severe losses in Eastern Europe as well as from other investments. The Austrian Volksbank Corporation has been restructured and partly taken over by the state. Another example of an organization that lost its cooperative character due to the crisis was the UK Co-operative Bank, which is now majority owned by external shareholders. In other countries, such as Italy, co-operatives that extended credit to the enterprises in their home regions during the crisis have suffered from the prolonged economic difficulties.

\section{Corporate Governance Issues in Financial Co-operatives}

The governance of a firm refers to the mechanisms for the internal control systems that make up the structure through which the objectives are defined, the means to reach the goals are determined, and the results are controlled. It involves a set of relationships among the shareholders, the boards of directors, the managers, and other stakeholders. The governance issue can be framed as an agency issue, where the separation between management and ownership, i.e. between the decision agent and the principal, has an 
impact both on efficiency and profitability. For several reasons, this mechanism is more complex in the case of co-operative banks: members can be both depositors and borrowers, thus the board and the managers should represent the contrasting interest of both; the board and the managers should represent the more general interests of the community (the stakeholders) and respect the collective orientation and mutual interest.

Nowadays, the most urgent problems in the governance of co-operative banks stem from their growth. On the one hand, the increase in the number of members and the spread of ownership impact on the voting mechanism make the individual position less important in the general assembly and reduce member mobilization. This can result in decreasing internal control of the management and in increased free-riding by members who may feel disempowered as the institution adds new members. On the other hand, growth requires sophisticated professional management in order to deal with the new and more complex financial situations; but the qualitative and quantitative reinforcement of management may favour the separation of ownership and control, thus intensifying agency problems. The weakening of democratic control on management by the general assembly may lead to opportunistic lending policies, a misappropriation of co-operative funds on behalf of the management for its own use, or a substantial misalignment between corporate philosophy and needs and will of members. Therefore, why members are motivated to be on the board becomes a more relevant question: it is more likely that directors follow their own interests, turning collective action away from its initial goals and giving rise to collectively less efficient solutions.

Not only growth makes it difficult to encourage existing members to exercise their ownership rights and responsibilities to oversee management. Other reasons for the 
declining participation in board elections include insufficient knowledge of the subjects discussed and the claim that the Board of Directors formulates the co-operative's policies without taking into account the needs of members. In any case, absenteeism from general meetings deprives members the possibility of understanding the reasoning behind the cooperative bank's operations. As a result, members judge the bank's performance mainly through their transactions and ignore the true reasons that shape how transactions are run and the consequences of the policy that is adopted.

Finally, the weak participation of members in the governance creates an inertia in the turnover of managers that leads to a clear group-thinking problem: a group (the board) that secludes itself away from critics (and self-critics) and finds a rationalization for all its decisions (right or wrong) not only lacks creativity and innovation, but tends also not to perform correctly the role of agent with respect to the owners (members) and the stakeholders in general. Sometimes, it may represent the interest of only one group of stakeholders and, in other cases, only that of the board.

\section{Regulatory Challenges of Co-operative Banks: Compliance Costs and Pressures to}

\section{Adopt the Features of Shareholder Banks}

The turbulent banking scene created by the crisis, in particular with the new Basel 2 and 3 requirements, has increased regulatory pressure on co-operative banks to strengthen both equity and profits, with a considerable impact on their internal organization. At the same time, the stricter regulatory framework that has been imposed and the institutional steps that have been taken toward introducing an EU banking union will introduce further challenges for co-operative banks. Since the costs of creating a union are expected to peak at a time when the banks will be required to build up their capital resources and finance economic 
growth, the underlying risk is that regulation will be seen again as a constraint to profit margins. In particular, the so-called stress-tests undertaken by the European Central bank (ECB) will probably increase the need to raise regulatory capital and ratios even among major co-operative banks.

The aftermaths of this recapitalization process could be that co-operative banks will struggle between retaining profits and adopting a counter cyclical behaviour and financing local economy. Thus, members and 'loyal' customers will find themselves with limited access to a solution that was readily available till the recent past. As the distance created between members and their bank deprived members from understanding that retained profits, i.e. the traditional source of capital of co-op banks, is probably the safest way to secure the presence of a co-op bank in the banking arena, the recapitalization procedure may re-enforce the perception that a co-op bank is not that different from any other banking institution. This vicious cycle may, of course, become even more intensive if co-operative banks opt for the employment of 'alternative' recapitalization solutions that would increase their dependency from external debt (the market and its 'players'). This, in addition, would decrease their degree of freedom in their quest for ethical, socially responsible, development-oriented banking behaviour.

Also the new regulations designed for the banking system could have severe consequences for co-operative banks, since they do not include a proportionality principle according to which the rules should be adapted for each type of bank based on its characteristics, in particular on small size. As an example, the strict impositions on the duties delegated to employees, i.e. one person should be devoted solely to the compliance, impacts on the minimal structure required to run a bank. The pursuit of economies of scale 
to reduce costs, especially personnel costs, will result into mergers and acquisitions and into an increase in size that may raise governance issues. This trend is likely to have a stronger impact on less integrated and centralized systems, such as in Germany and Italy, where single co-operative banks have large autonomy from Federations.

\section{Challenges faced by Co-operative Banks in Terms of their Mission and of Establishing New Co-operative Banks}

As noted in the beginning of this article, co-operative banks, especially those of the Raiffeisenian variety, have been promoting the economic well-being of the economically disadvantaged. Nevertheless, there seems to be a tendency to converge into economic mainstream. Being self-help organization, co-operatives rely on economically stable middle-class members. Over time, this may lead to the exclusion of the poorest strata from membership. Thus, co-operatives need to constantly redefine their vision. An economic analysis of co-operatives starting from aggregating member preferences may justify the gentrification of co-operatives. However, it would be more consistent with co-operative values to have a more inclusive vision and co-operatives that include the economically disadvantaged in their field of membership. Many North American credit unions represent examples of this.

Retaining member participation in a situation where co-operatives are becoming larger through members represents a second challenge. As explained above, mergers are the result of a combination of technological changes and of pressures from the regulator, the supervisors, and often also from inside the group. Mergers tend to increase the distance between members and management. Co-operatives need either to consider new ways to incentivize members to participate in governance or to accept permanently lower 
participation. The dynamics of entry and exit in the co-operative population also pose important challenges. Even though co-operatives have advantages in the form of lower exit rates - as suggested by their greater resilience during times of crisis - they suffer severe problems of entry. In most countries, the main periods of entry of co-operatives took place in late nineteenth and early twentieth centuries. As soon as nationally encompassing coverage of co-operatives was achieved, the internal non-competition rules of co-operatives discouraged entry of new co-operatives. During that period, establishing credit cooperatives was relatively easy and minimum capitalization requirements, if any, were at low levels. Today the situation is completely different as there are stringent requirements for minimum equity capital and demanding operational requirement for banks. In some countries with small or no co-operative banks, including Belgium and Israel, there have been attempts to create new co-operatives, but these initiatives have proceeded very slowly. In the North American system, where financial co-operatives (credit co-operatives) are under their own regulatory framework, there is more entry, but even in this case it has been very limited. The lack of entry is worrisome, because in the long run the population cannot survive without new entry, even if the existing units were more resilient than their competitors.

Ultimately, the case for retaining co-operative banks rests on preserving the diversity in the financial markets. Indeed, it has been argued that greater diversity in the micro-level creates favourable conditions for macro-stability. This stability can be threatened in two ways: either through the disappearance of co-operative banking organizations or through their continued nominal existence, but without any operations difference with shareholder banks. In the current situation, this diversity still exists in some countries (notably Germany and France), while it is under threat in others (e.g. Italy) and 
has practically disappeared in some others (the UK). In order to counter such worrisome trends it is necessary to find ways to revitalize co-operatives where they exist and make sure new financial co-operatives can enter the market.

\section{REFERENCES}

Alexopoulos, Y., Catturani, I. and Goglio, S. (2013). 'Searching for a Model of Governance in Cooperative Banking’, in Brazda, J., Dellinger, M. and Rössl, D. (Eds.), Genossenschaften im Fokus einer neuen Wirtschaftspolitik, Berlin et al.: LIT Verlag, pp. 707-731.

Alexopoulos, Y. and Goglio, S. (2011). 'Financial Cooperatives: Problems and Challenges in the PostCrisis Era', Journal of Rural Cooperation, 39(1): 34-47.

Alexopoulos, Y. and Goglio, S. (2013). 'Introduction: Cooperative Finance and Sustainable Local Development', in Goglio, S. and Alexopoulos, Y. (eds.), Financial Cooperatives and Local Development. London: Routledge, pp. 1-18.

Ayadi, R., Llewellyn, D. T., Schmidt, R. H., Arbak, E., \& Pieter De Groen, W. (2010). Investigating diversity in the banking sector in Europe: key developments, performance and role of cooperative banks. Brussels: Centre for European Policy Studies.

Birchall, J. (2013). Resilience in a downturn: The power of financial cooperatives. Geneva: International Labour Office.

Desrochers, M., \& Fischer, K. P. (2005). The power of networks: integration and financial cooperative performance. Annals of public and cooperative economics, 76(3), 307-354.

Ferri, G. \& Kalmi, P. (2014). Only Up: Regulatory Burden and Its Effects on Credit Unions. Filene Institute Research Report. 
Ferri, G., Kalmi, P., \& Kerola, E. (2014a). Does bank ownership affect lending behavior? Evidence from the Euro area. Journal of Banking \& Finance, 48, 194-209.

Ferri, G., Kalmi, P., \& Kerola, E. (2014b). Organizational Structure and Exposure to Crisis among European Banks: Evidence from Rating Changes. JEOD, 3(1), 35-55.

Ferri, G., Kalmi, P., \& Kerola, E. (2015). Organizational structure and performance in European banks: A reassessment. Advances in the Economic Analysis of Participatory and Labor-Managed Firms (forthcoming).

Girardone, C., Nankervis, J. C., \& Velentza, E. F. (2009). Efficiency, ownership and financial structure in European banking: A cross-country comparison. Managerial Finance, 35(3), 227-245.

Goglio S. and Alexopoulos Y. (2014). Cooperative Banks at a Turning Point?, JEOD, Vol.3, Issue 1 (2014) 1-8

Goglio S. and Leonardi A. (2012). The motivations of economic behavior: the case of cooperative credit, JEOD, Volume 1, Issue 1 (2012) 65-84.

Groeneveld, J. M., \& de Vries, B. (2009). European cooperative banks: first lessons from the subprime crisis. The International Journal of Cooperative Management, 4(2), 8-21.

Guinnane, T. W. (2001). Cooperatives as information machines: German rural credit cooperatives, 1883-1914. The Journal of Economic History, 61(02), 366-389.

Hesse, H. and Cihak, M. (2007). 'Cooperative Banks and Financial Stability', IMF Working Paper, $07 / 2$.

Kontolaimou, A., \& Tsekouras, K. (2010). Are cooperatives the weakest link in European banking? A non-parametric metafrontier approach. Journal of Banking \& Finance, 34(8), 1946-1957. 
Lang, G., \& Welzel, P. (1996). Efficiency and technical progress in banking Empirical results for a panel of German cooperative banks. Journal of Banking \& Finance, 20(6), 1003-1023.

Mäkinen, M., \& Jones, D. C. (2015). Comparative Efficiency Between Cooperative, Savings and Commercial Banks in Europe Using the Frontier Approach. Annals of Public and Cooperative Economics, forthcoming.

Mester, L. J. (1993). Efficiency in the savings and loan industry. Journal of Banking \& Finance, 17(2), 267-286.

Michie, J. (2011). Promoting corporate diversity in the financial services sector. Policy studies, 32(4), 309-323.

Wheelock, D. C., \& Wilson, P. W. (2011). Are credit unions too small?. Review of Economics and Statistics, 93(4), 1343-1359.

Wilcox, J. A., \& Dopico, L. G. (2011). Credit union mergers: efficiencies and benefits. FRBSF Economic Letter, 2011, 28. 